\title{
Study on the Analysis regarding the Connection Network of Design Inspirations pursued by Modern Fashion Designers - Focus on the Concept of Fashion Collections -
}

\author{
Young Sam Kim ${ }^{1)}$, Jang Hyeon Kim ${ }^{1)}$, and Sung Soo Kim ${ }^{2) \dagger}$ \\ ${ }^{1)}$ Dept. of Fashion Design, College of Arts, Chung-Ang University; Anseong, Korea \\ ${ }^{2)}$ Dept. of Fashion, Graduate School, Chung-Ang University; Seoul, Korea
}

\begin{abstract}
This research explores diachronic fashion design trends through a structure analysis of a connection network based on fashion show concepts implemented by modern fashion designers from S/S 2009 to F/W 2013. The findings from this research are as follows. First, four categories affect the inspiration and thinking of design: the experience of the designer, social atmosphere and phenomena, natural sensitivity (or formative characteristics of natural objects), and the influence and quality of other fields. Second, in cases where the designers' experiences influenced design inspiration and thinking, designers express personal memories with keywords like high school, grandmother's closet, prom, beauty and the beast, heritage, past, and reminiscence through design elements such as lines, silhouettes, materials, and colors. Third, the representative example of the social atmosphere and phenomena that influenced design inspiration and thinking was the 2008 Global Financial Crisis that reflected the social climate through design concepts of keywords such as Recession, Black, Economy, US, Depression, Gray, Dark Age, White and New York. Fourth, inspired by nature and the formative characteristics in design, the designers employed ornamental elements to collections and design concepts that focused on nature words connected to light, sun, wild, dirt, rock, moss, and trees. Fifth, the designers took their ideas from different fields of personal interest in the arts, science and humanities (sports, architecture, sculpture, painting, and literature) that were decisive in determining materials, design colors and silhouettes. The theme of architecture was analyzed as a central element that had an ongoing impact on the concepts of designers.
\end{abstract}

Key words : design inspirations, fashion designer, connection network, the analysis of diachronic, the concept of fashion show

\section{Introduction}

The structure of the fashion industry in contemporary society has transformed from a postindustrial revolution manufacture based industry to a new fashion industry that incorporates various changes in creative and unique ideas. This phenomenon is indicative of a fashion industry traditionally influenced exclusively by the field of art that is now inspired by wide-ranging areas of various perspectives. In particular, the overall costume concepts suggested by designers presented in fashion shows and formative styles provide an opportunity to consider the creativity of fashion designers . This is significant because design concept plays an important part in the background of how fashion design came about and how the concept of a fashion show became an opportunity to realize the origin of design ideas or the creativity of the designer.

The existing studies in relation to this research include: 1) Generating a creative idea and developing a fashion design model (Choi, 2001). 2) Research on fashion design conception analyzed

$\dagger$ Corresponding author; Sung Soo Kim

Tel. $+82-31-670-3278$

E-mail: ksskimsungsu@hanmail.net by a check list method (Lee, 2006). 3) A study on constructive apparel design techniques with constructive line and plane (Lee, 2007). 4) A study on fundamental fashion phenomena as influenced by perception and memory (Kim, 2010) 5) Analysis of trench coat design by the fashion design idea method (Kim, 2012). 6) A study on transformable fashion design through the idea of conversion (Nam, 2012). 7) A comparative study on creativity influencing factors for fashion designers centered on the perspectives of M. Csikszentimihalyi \& H. Gardener (Lee, 2013).

There have been numerous studies on fashion design views that focused on fashion design analysis vis-à-vis creative thinking that suggest designs based on results or exploring the dispositions of fashion designers based on theories suggested by scholars from other fields. Accordingly, the research team of this study set a different goal from prevailing studies to analyze fashion design trends that targeted fashion show concepts that have become the origins of design thinking.

This research explores diachronic fashion design trends through a structure analysis of a connection network based on fashion show concepts implemented by modern fashion designers from S/S 2009 to F/W 2013. We identify social and cultural phenomena displayed 
in relation to fashion trends as well as encourage the Korean fashion industry by finding factors and features to improve the development of fashion culture. It is salient to identify these trends because younger students, who wish to become a fashion designers, can reference this research as educational material for creative thinking.

The detailed research issues for this research are as follows. First, a general review was conducted in regards to the meanings and symbols of design thinking and concept in the fashion design field. Second, connection networks were analyzed based on existing studies in various fields. Third, using UCINET 6.0 for the analysis of social network data, the connection networks of design thinking pursued by contemporary fashion designers focused on keyword concepts used by designers over the past five years. Lastly, comparison analysis research (as shown through a connection network analysis) will be conducted on the characteristics and seasonal diachronic fashion design trends.

Research methodologies included theoretical research on literature such as previous research papers, Korean and foreign books, the internet, technical books and major collection related websites (www.firstviewkorea.com, www.samsungdesign.net, and www.style.com). Sources were investigated in regards to the origin or inspiration of ideas and the fashion show concept from a design perspective. Keywords were then drawn in relation to concepts that the designers pursued in fashion collections over the past five years to review as a research target and UCINET 6.0 was introduced to induce characteristics from the connecting structure concerning the concept followed by each designer.

The research period was from S/S 2009 to F/W 2013 and the targets were designers who held fashion shows of the ready-to-wear women's wear of the four major collections in New York, Milan, Paris and London. With the 886 design concepts gathered primarily, a professional research team of more than five master's and doctoral degree holders in fashion design areas analyzed materials and selected a final 445 concepts related to design thinking to use as analysis material for research. Women's wear and ready-to-wear were considered appropriate for research and to analyze the aspects of design thinking that concentrated on women's wear concepts that tend to accept the trends of a certain period sensitively in terms of design silhouette and color relative to men's wear as well as ready-to-wear that has a property in that the designers reflect the latest trends and social and cultural climate of the time.

\section{Theoretical Background}

\subsection{General Study on the Design Thinking and Concept in the Fashion Design Field}

Dictionary definitions about design thinking articulate that 'design' signifies "the plan or drawing of a figurative piece with a practical purpose like clothing, merchandise or architecture" (The National Institute of the Korean Language, 2014), and 'thinking' means "presenting a new idea or an original idea" (Essence Korean Language Dictionary, 2013). The notion of design thinking changes existing things in a more advanced direction or develops something original from a unique perspective created from human imagery.

Proceeding research on design thinking by Kong (2003) said that 'thinking' implies 'devising an idea' that refers to the artistic activities of drawing creative ideas and that creativity indicates producing something new by converting and breaking from established things. Lee (2007), whose studies focused on the fashion design thinking method, emphasized that fashion design requires new emotional creativity that results from complex interactions among different factors such as technique, function, and sensibility as well as the difficult challenge of new thinking by a designer who is responsible for the important element of creative design. In the research on the lexical characteristics of the design thinking development process, Kim (2014) stated that the importance of such an analogical association process must be recognized in a design field which constantly involves creative ideas.

Design thinking is creating newness in a method of converting or escaping from existing elements with a specific purpose and starts from the intense training of combining internal components such as designer's emotion, technique, and function.

Designers' thinking is applied to developing fashion designers' invisible and abstract concepts into practical fashion designs for the fashion design field and is a symbol implying the concept of design thinking in the designers' collections held every year.

The etymology of 'concept' in design concept is the Latin 'conceptus', denoting the 'collecting and gathering of ideas'; consequently, the designer produces designs based on concepts connoting the ideas to deliver messages to the public (Choi, 2009). The National Institute of the Korean Language (2014) explained that the concept is "a main idea intended to show a certain work, product, performance or event."

In preceding research about the design concept, Kim (2014) said that the logical procedure for a designer is in this order of ideas through intuition in the early design stage; subsequently, you must use theories and analyses to test the findings and redraw intuitions in the integration stage.

The design concept is both mental thinking and the idea that the producer wants to reveal from the specific object through which the design message can be delivered to the public through concepts. The design concept is a critical stage where the designer reads indi- 
vidual ideology and the overall climate of society and contains design ideas that the public (or the individual) desires.

Design thinking is non-visible and a representative message that conveys a designersthe idea that the producer wants to reveal from the specific objin a text form known as 'Concept'.

\subsection{General Study on the Connection Network Analysis}

Introducing the principle that group's characteristics are stipulated by the individual interacting and vice-versa, Simmel proposed one of the principle mechanisms to analyze the contemporary connection network. He showed the possibility of organizing social networks in the form of the strategic maneuvering of all kinds between groups and individuals physicalized and institutionalized. He argued that the individual is where various groups intersect. The group is then created in which the individuals intersect and develops as a concept of duality in terms of the network considered to be connected as the concept of social symmetry (Kim, 2012).

Previous research on the analysis of networks by Kim (2003) indicated that the network analysis creates microscopic views that capture interrelations among subjects separately and partially look with general and broad macroscopic viewpoints. The analysis of network targets to analyze the relational properties among variables that also induces the characteristics of the structures and network forms as well as explains the features of a system as the relationship and activities of units composed of the system. Hong et al. (2014) considered that it is possible to explain the mechanism of the network formation through a network analysis based on a socio-cultural background that provides relationships among various performers first and then process those through comparative research according to network analysis that induces relationships with standards measured by the centrality.

Network analysis explicates relations and structures to a given phenomenon by the density and centrality organized in a network form. The centrality to understand connectional forms of relations among subjects is critical to an overall and macroscopic view on the group and phenomenon. Network analysis was used in various areas (such as the analysis of the communication structures of science talent, policy network research, and economic policies pursued by former Korean presidents) and represented a method to analyze the structure and phenomenon of a specific field.

\subsection{General contemplation on Fashion collection themes}

A 'Collection' according to The National Institute of the Korean language (2015) is "a group of objects or an amount of material" and theme refers to a subject of thought expressed as Logos by Aristotle. The word theme expresses the canon of expression in a sentence in a rhetorical field that is almost in the same meaning of a modern symbol that is currently used in the culture and arts field (Doosan Encyclopedia Doopedia 2015). A fashion collection theme can be defined to represent the thought or meaning of a fashion group.

Studies on fashion collection themes show that Perna (1987) defined theme as a wide network repeatedly used to: produce and unify themes, find seasonal trends, interpret unified principles, and handle consumer sentiment. Theme sets images which can be predicted by consumers who are potential purchasers based on next season research and fashion forecast analysis done by designers that are extended to all product processes for production and sales. (Kim, 2003) Consequently, Burns \& Bryant (2002) indicated that colors from fashion collections, historic past, ethnic, materials, decorations, certain events, or the spirit of the age are shown repeatedly as 'Theme'. Theme is used in fashion shows and applied to various parts from the image maps of products, product shape design, and selecting concrete materials for VMD promotional activities (Kim, 2003).

Fashion collection theme is variously expressed in fashion collections after setting images researched from factors that influence fashion as a concrete motif. These themes analyze fashion flows and look into current fashion trends.

\section{Network Analysis on the Design Thinking that the Contemporary Designers Pursued Over the Past Five Years}

The concepts of contemporary fashion designers implicitly textualized design intentions and entire collections. This means that the concepts of designers involve inner elements (designers' personal ideologies, identities, memories, and experiences) as well as external elements (social climate, conditions of the times, and typological components) that enable them to identify structures to connect a concept and design thinking.

The research team conducted a network analysis of design thinking related concepts of the designers who held ready-to-wear women's clothing fashion shows in the four major collections (New York, Milano, Paris and London) from S/S 2009 to F/W 2013 using UCINET 6.0 software. Examining the network analysis of S/S and F/W 2009 regarding the design thinking that the fashion designers pursued. Fig. 1 showed that the S/S season 2009 first resulted in the experiential aspects that could be converged in keywords such as Northern Europe, White Night, Indiana Jones, Out of Africa, Film, Beach, Travel, Alexander Girard, Charlie's Angels, Safari, Capri Island, the Past of Europe and Dance, and second trends oriented toward social climate and phenomenon with keywords such as 80 s, Hippie, Rock, Minimalism, Female, Environ- 


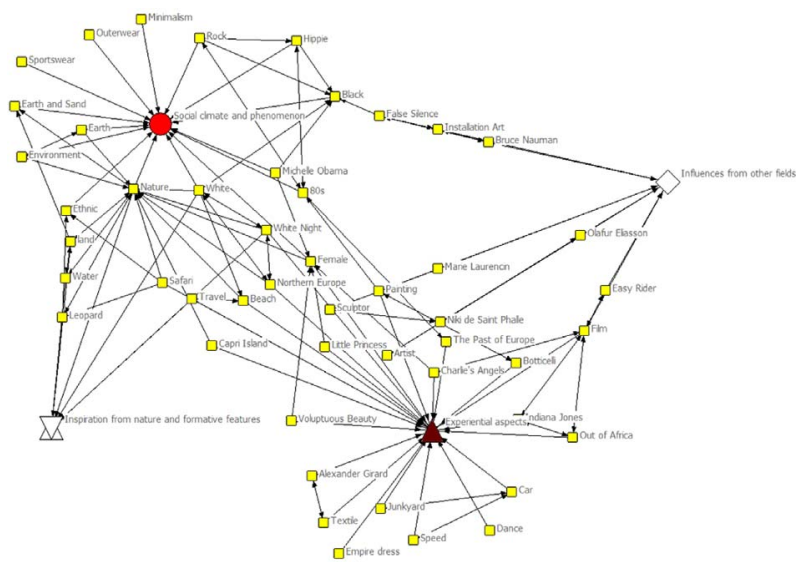

Fig. 1. Analysis regarding connection network of design inspirations pursued by modern fashion designers in $2009 \mathrm{~S} / \mathrm{S}$.

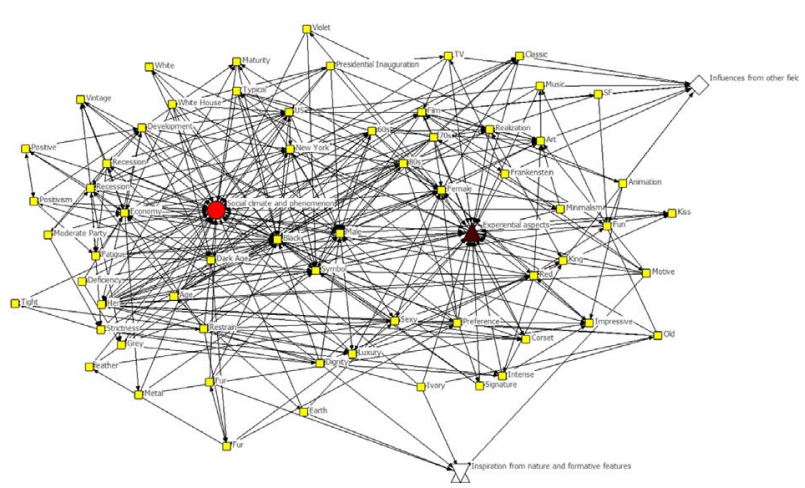

Fig. 2. Analysis regarding connection network of design inspirations pursued by modern fashion designers in $2009 \mathrm{~F} / \mathrm{W}$.

ment, Earth, Black, and Michelle Obama. The F/W season in 2009 (Fig. 2) showed the experiential aspects with keywords like Sexy, Dark Age, Kiss, Signature, Motive, Film, Ivory, Old, Music, Frankenstein, Classic, Reproduction and TV, whereas the social climate and phenomenon seemed to be dispersed with keywords such as Black, 80s, 60s, 70s, New York, Development, Minimalism, Dark Age, Restrain, Vintage, Fur, Fatigue, Recession, Moderate Party, US, Tight, Earth, Age, Maturity, Positive, Deficiency, White House, Presidential Inauguration, and TV.

The network analysis of S/S and F/W 2010 on the design thinking that fashion designers pursued, the experiential aspects of the $\mathrm{S} /$ S season in 2010 (Fig. 3) resulted in keywords such as Traveler, Theater, Essence, Ballet, Opera, Alice In Wonderland, Film, Camping, Childhood, Sicilian, Life, Party, Realization, Pioneer, the Great Depression, City, Punk, and Classic contrasting from the trends on the inspiration from nature and formative features such as Hay, Object, Wind, Resort, Minimalism, American, Beach, Sea, Female, Dawn, Honeycombed, Farm, Grain and Head Accessory. The F/W season in 2010 (Fig. 4) show that the concepts that

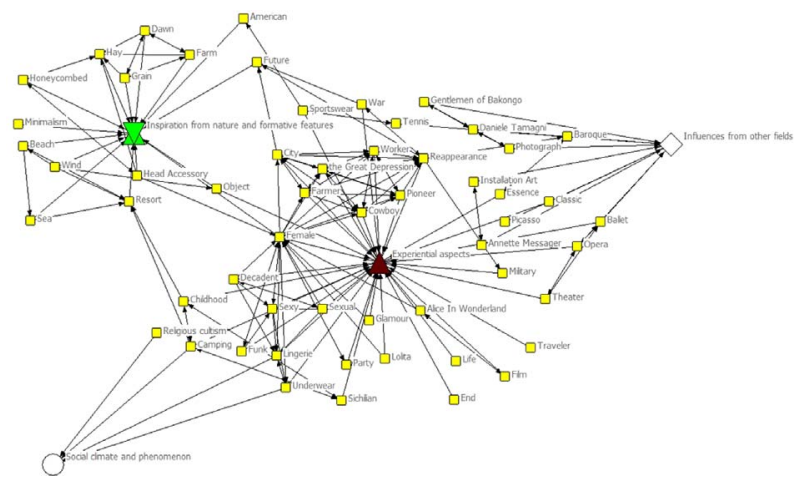

Fig. 3. Analysis regarding connection network of design inspirations pursued by modern fashion designers in $2010 \mathrm{~S} / \mathrm{S}$.

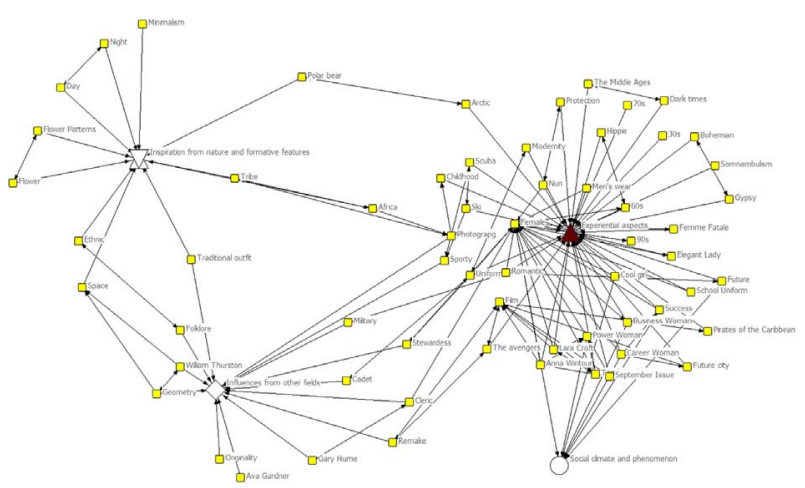

Fig. 4. Analysis regarding connection network of design inspirations pursued by modern fashion designers in $2010 \mathrm{~F} / \mathrm{W}$.

became the origins of design influenced by experiential aspects illustrated with keywords such as Somnambulism, School Uniform, Career Woman, Female, 30s, 70s, Tomb Raider, September Issue, 90s, 60s, Pirates of the Caribbean, Flower Pattern, The Avengers, Dark times, Business Woman, Ski, Scuba, Elegant Lady, Arctic, Childhood, Romantic, Lara Croft and Anna Wintour.

With reference to the network analysis of S/S and F/W 2011, regarding the design thinking that the fashion designers pursued, the design concept of the S/S season in 2011 (Fig. 5) can be represented with keywords such as Scent Of Flower, Cherry Blossoms, Nature, Texture Of Wood, Foliage, Tradition, Waltz Of Spring, Female, Curvaceousness, Mexico, Resort, Sahara Desert, Dye, Black, Latin America, Minority, Rose, Animal Kingdom, Feminine, Garden, Flower, White, Blue, Green, Natural, Warn, Pastel and Orange that focused on the inspiration from nature and formative features, while the F/W season in 2011 (Fig. 6) were more interested on influences from other fields such as Baroque, Minimal, Sportswear, Tristan, Navajo, Painter, Modern, Helmut Newton, Rosy Daybreak, Gothic, Church, Stained-Glass, Medieval Knights, Armor, Crusaders, Charles James, Black Swan, Night 


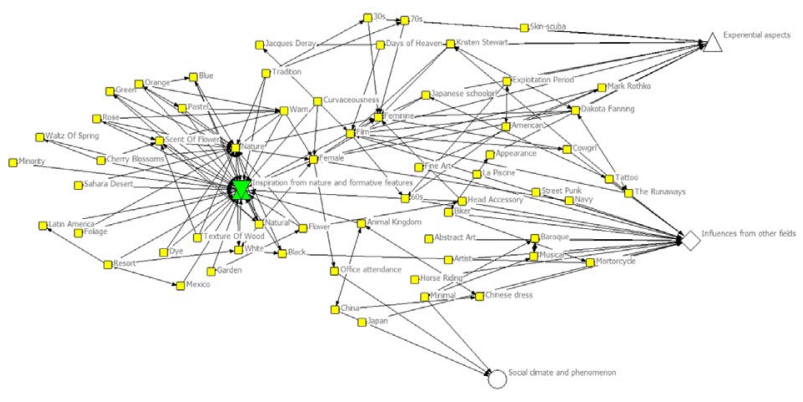

Fig. 5. Analysis regarding connection network of design inspirations pursued by modern fashion designers in $2011 \mathrm{~S} / \mathrm{S}$.

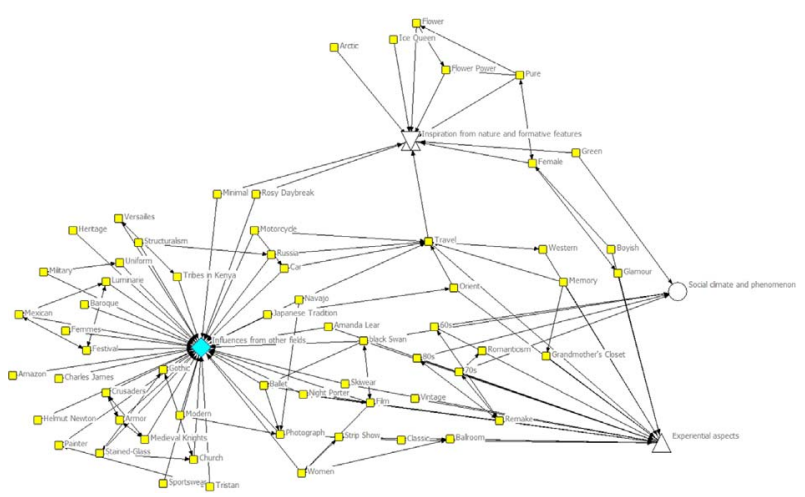

Fig. 6. Analysis regarding connection network of design inspirations pursued by modern fashion designers in $2011 \mathrm{~F} / \mathrm{W}$.

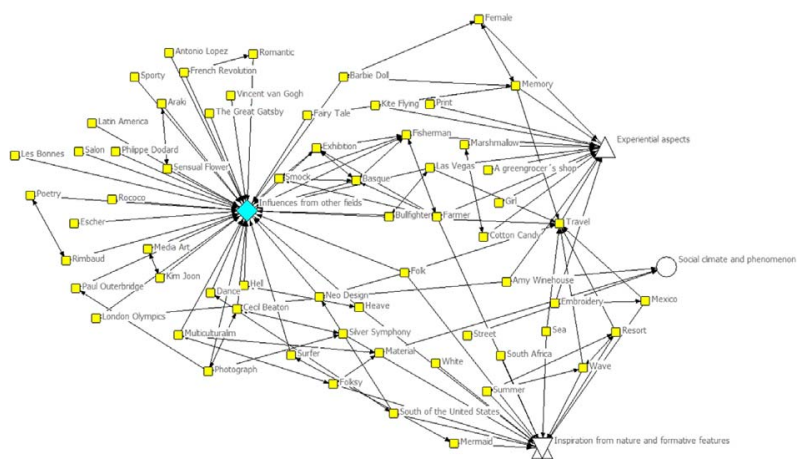

Fig. 7. Analysis regarding connection network of design inspirations pursued by modern fashion designers in $2012 \mathrm{~S} / \mathrm{S}$.

Porter, Film, Femmes, Women, Motorcycle, Mexican, Festival, Luminarie, Japanese Tradition, Photograph, Amanda Lear, Amazon, Heritage, Russia, Structuralism, Military, Uniform, Skiwear, Ballet, Car, Versailles and Tribes in Kenya.

Network analysis was divided into S/S and F/W in 2012 regarding the design thinking that fashion designers pursued evidenced that the S/S season in 2012 (Fig. 7) were on the subject of influences from other fields with keywords such as Cecil Beaton, Photograph, Multiculturalism, Sporty, French Revolution, Romantic,

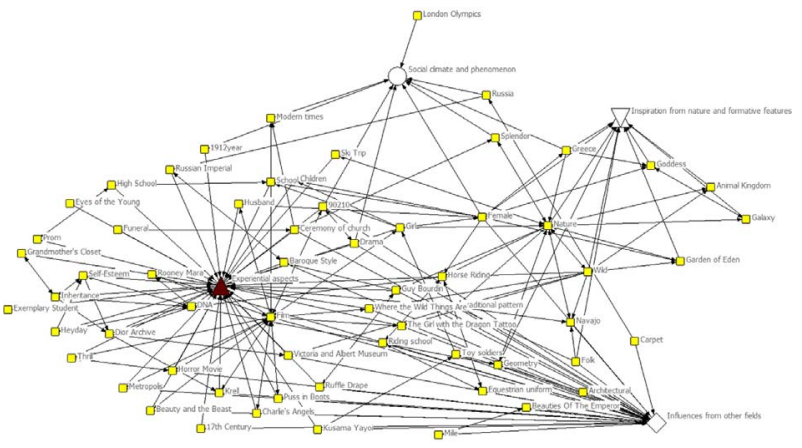

Fig. 8. Analysis regarding connection network of design inspirations pursued by modern fashion designers in $2012 \mathrm{~F} / \mathrm{W}$.

Barbie Doll, Escher, Hell, Heave, Latin America, Neo Design, Les Bonnes, Bullfighter, Basque, Exhibition, Rimbaud, Poetry, Media Art, Rococo, Salon, Kim Joon, Araki, Sensual Flower, Dance, Folk, Philippe Dodard, Fairy Tale, Paul Outerbridge, London Olympics, Antonio Lopez, The Great Gatsby, and Vincent van Gogh.

The F/W season in 2012 (Fig. 8) demonstrated a tendency to emphasize the experiential aspects that combine in keywords such as Film, Ruffle Drape, Dior Archive, DNA, Self-Esteem, Girl, Charlie's Angels, Where the Wild Things Are, The Girl with the Dragon Tattoo, Rooney Mara, Krell, Husband, Children, School, Inheritance, High School, Prom, Drama, Funeral, Ski Trip, Exemplary Student, 17th Century, Beauty and the Beast, Horror Movie, Thrill, Heyday, Eyes of the Young, Grandmother's Closet, and Puss in Boots.

Through network analysis, the design thinking that the fashion designers pursued in S/S and F/W 2013 (Fig. 9) seemed to be more attentive to the influence of other fields in keywords such as Architecture, Optimism, Maximalism, Modern, Anna Magnani, Mathematical, Geometrical, Classic, Romantic, Black, White, Bauhaus, Architectural Beauty, Abstract Painting, Josef Albers, Steven Mei-

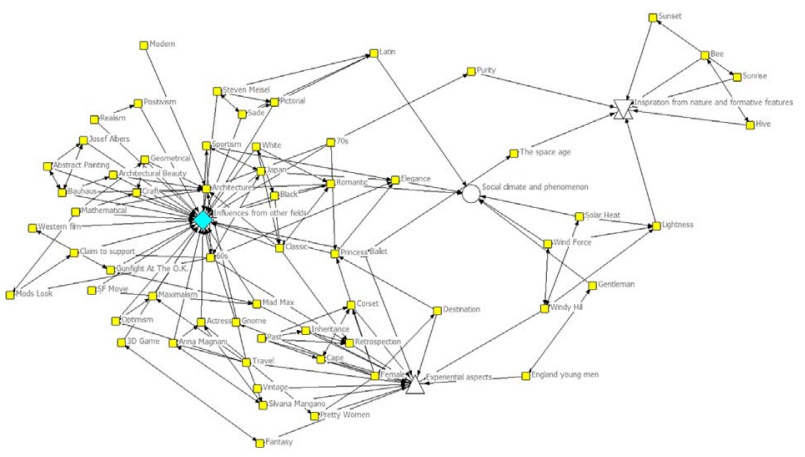

Fig. 9. Analysis regarding connection network of design inspirations pursued by modern fashion designers in $2013 \mathrm{~S} / \mathrm{S}$. 


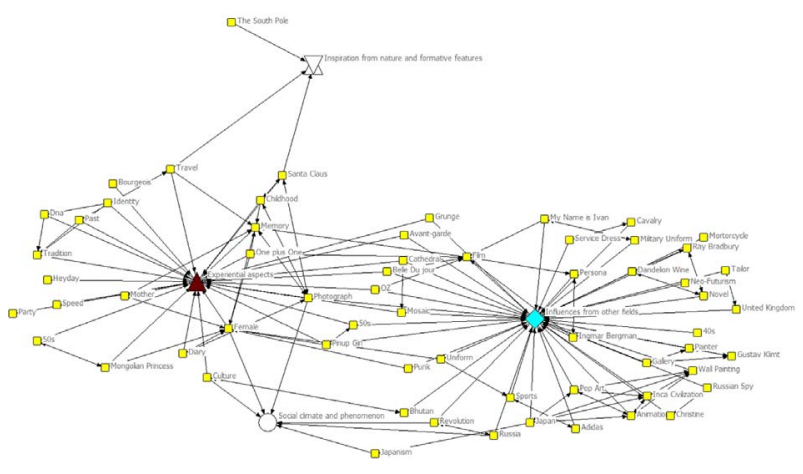

Fig. 10. Analysis regarding connection network of design inspirations pursued by modern fashion designers in $2013 \mathrm{~F} / \mathrm{W}$. sel, Sade, Pictorial, Ballet, 3D Game, Realism, Positivism, Craft, Princess, Gnome, and Sportism. For the F/W season 2013 (Fig. 10), keywords headed in two directions of experiential aspects such as Party, 50s, Past, Travel, Childhood, Photograph, Santa Claus, Memory, OZ, Female, Heyday, Dairy, Culture, Tradition, Identity, Mosaic, Cathedral, DNA, Mother and influences from other fields like Inca Civilization, Wall Painting, Japan, Animation, Pop Art, Persona, Ingmar Bergman, Film, Punk, Pinup Girl, Russian Spy, Christine, Adidas, Gustav Klimt, Painter, Gallery, Tailor, NeoFuturism, Dandelion Wine, Novel, Ray Bradbury, Photograph, Uniform, Russia, Revolution, OZ, My Name is Ivan, Military Uniform, Motorcycle, Grunge, Cavalry, Service Dress, Bhutan, Sports,

Table 1. Network Analysis of the Design Thinking Pursued by Contemporary Designers from 2009 to 2013

\begin{tabular}{|c|c|c|}
\hline Year & Keyword & Type \\
\hline $\begin{array}{l}2009 \\
\mathrm{~S} / \mathrm{S}\end{array}$ & $\begin{array}{l}\text { Northern Europe, white night, Indiana Johns, Out of Africa, film, beach, travel, Alexander Girard, Charlie's Angels, } \\
\text { Safari, Capri Island, the past of Europe, dance, } 80 \mathrm{~s} \text {, hippie, rock, minimalism, female, environment, earth, black, } \\
\text { Michelle Obama }\end{array}$ & $\begin{array}{l}\text { Experiential Aspect } \\
\text { Social Climate and } \\
\text { Phenomenon }\end{array}$ \\
\hline $\begin{array}{l}2009 \\
F / W\end{array}$ & $\begin{array}{l}\text { sexy, dark age, kiss, signature, motive, film, ivory, old, music, Frankenstein, classic, reproduction, TV, black, } 80 \mathrm{~s} \text {, } \\
60 \mathrm{~s} \text {, economy, 70s, New York, development, minimalism, restrain, vintage, fur, fatigue, recession, moderate, party, } \\
\text { US, tight, earth, age, maturity, positive, deficiency, White House, presidential inauguration }\end{array}$ & $\begin{array}{l}\text { Experiential Aspect } \\
\text { Social Climate and } \\
\text { Phenomenon }\end{array}$ \\
\hline $\begin{array}{l}2010 \\
\mathrm{~S} / \mathrm{S}\end{array}$ & $\begin{array}{l}\text { traveler, theater, essence, ballet, opera, Alice in Wonderland, film, camping, childhood, Sicilian, life, party, } \\
\text { reproduction, pioneer, the Great Depression, city, punk, classic, hay, object, wind, resort, minimalism, American, } \\
\text { beach, sea, female, dawn, honeycombed, farm, grain, head accessory }\end{array}$ & $\begin{array}{c}\text { Experiential Aspect } \\
\text { Sensibility of Nature and } \\
\text { Formative Feature }\end{array}$ \\
\hline $\begin{array}{l}2010 \\
\mathrm{~F} / \mathrm{W}\end{array}$ & $\begin{array}{l}\text { somnambulism, school uniform, career woman, female, 30s, 70s, Tomb Raider, September issue, 90s, 60s, Pirates } \\
\text { of the Caribbean, flower pattern, the Avengers, the Dark Ages, business woman, ski, scuba, elegant lady, the Arctic, } \\
\text { childhood, romantic, Lara Croft, Anan Wintour }\end{array}$ & Experiential Aspect \\
\hline $\begin{array}{c}2011 \\
\mathrm{~S} / \mathrm{S}\end{array}$ & $\begin{array}{l}\text { scent of flower, cherry blossoms, nature, texture of wood, foliage, tradition, waltz of spring, female, } \\
\text { curvaceousness, Mexico, resort, Sahara Desert, dye, black, Latin America, minority, rose, animal kingdom, } \\
\text { feminine, garden, flower, white, blue, green, natural, warm, pastel, orange }\end{array}$ & $\begin{array}{c}\text { Sensibility of Nature and } \\
\text { Formative Feature }\end{array}$ \\
\hline $\begin{array}{l}2011 \\
F / W\end{array}$ & $\begin{array}{l}\text { Baroque, minimal, sportswear, Tristan, Navajo, painter, modern, Helmut Newton, rosy daybreak, gothic, church, } \\
\text { stained-glass, medieval knight, armor, crusader, Charles James, Black Swan, Night Porter, film, Femmes, women, } \\
\text { motorcycle, Mexican, festival, Luminarie, Japanese tradition, photograph, Amanda Lear, Amazon, heritage, } \\
\text { Russia, structuralism, military, uniform, skiwear, ballet, car, Versailles, tribes in Kenya }\end{array}$ & Influence of Other Fields \\
\hline $\begin{array}{l}2012 \\
\mathrm{~S} / \mathrm{S}\end{array}$ & $\begin{array}{l}\text { Cecil Beaton, photograph, multiculturalism, sporty, French revolution, romantic, Barbie doll, Escher, hell, angel, } \\
\text { Latin America, neo design, Les Bonnes, bullfighter, Basque, exhibition, Rimbaud, poetry, media art, Rococo, salon, } \\
\text { Kim Joon, Araki, Sensual Flower, dance, folk, Philippe Dodard, fairy tale, Paul Outerbridge, London Olympics, } \\
\text { Antonio Lopez, the Great Gatsby, Vincent van Gogh }\end{array}$ & Influence of Other Fields \\
\hline $\begin{array}{l}2012 \\
\mathrm{~F} / \mathrm{W}\end{array}$ & $\begin{array}{l}\text { film, ruffle drape, Dior Archive, DNA, self-esteem, girl, Charlie's Angels, Where the Wild Things Are, The Girl } \\
\text { with the Dragon Tattoo, Rooney Mara, Krell, husband, children, school, inheritance, high school, prom, drama, } \\
\text { funeral, ski trip, exemplary student, } 17^{\text {th }} \text { century,Beauty and the Beast, horror movie, thrill, heyday, eyes of the } \\
\text { young, grandmother's closet, Puss in Boots }\end{array}$ & Experiential Aspect \\
\hline $\begin{array}{c}2013 \\
\mathrm{~S} / \mathrm{S}\end{array}$ & $\begin{array}{l}\text { architecture, optimism, maximalism, modern, Anna Magnani, mathematical, geometrical, classic, romantic, black, } \\
\text { white, Bauhaus, architectural beauty, abstract painting, Josef Albers, Steven Meisel, Sade, pictorial, ballet, 3D } \\
\text { game, realism, positivism, craft, princess, gnome, sportism }\end{array}$ & Influence of Other Fields \\
\hline $\begin{array}{l}2013 \\
\mathrm{~F} / \mathrm{W}\end{array}$ & $\begin{array}{l}\text { party, 50s, past, travel, childhood, photograph, Santa Cruz, memory, OZ, female, heyday, dairy, culture, tradition, } \\
\text { identity, mosaic, cathedral, DNA, mother, Inca Civilization, wall painting, Japan, animation, pop art, persona, } \\
\text { Ingmar Bergman, film, punk, pinup girl, Russian spy, Christine, Adidas, Gustav Klimt, painter, gallery, tailor, neo- } \\
\text { futurism, Dandelion Wine, novel, Ray Bradbury, photograph, uniform, Russia, revolution, OZ, My Name is Ivan, } \\
\text { military uniform, motorcycle, grunge, cavalry, service dress, Bhutan, sports, mosaic, cathedral, Belle Du jour, } \\
\text { avant-garde }\end{array}$ & $\begin{array}{c}\text { Experiential Aspect } \\
\text { Influence of Other Fields }\end{array}$ \\
\hline
\end{tabular}


Table 2. Types of Design Thinking that Contemporary Fashion Designers Pursued Over the Past Five Years

\begin{tabular}{ll}
\hline $\begin{array}{l}\text { Keywords for design concepts pursued by contemporary fashion designers over } \\
\text { the past five years }\end{array}$ & $\begin{array}{l}\text { Design thinking type that contemporary fashion } \\
\text { designers pursued over the past five years }\end{array}$ \\
\hline $80 \mathrm{~s}, 60 \mathrm{~s}, 70 \mathrm{~s}$, kiss, film, music, Frankenstein, fun, reproduction, Northern Europe, beach, travel, \\
$\begin{array}{l}\text { Charlie's Angels, dance, car, party, past, gallery, UK, Dandelion Wine, novel, childhood, } \\
\text { photograph, memory, heyday, diary, tradition, identity, grandmother's closet, film, DNA, self- }\end{array}$ & $\begin{array}{l}\text { Types that the designer's experiential aspects that } \\
\text { han effect on the design inspiration and thinking }\end{array}$
\end{tabular}
esteem, mother...

black, economy, male, New York, development, dark age, luxury, fatigue, recession, US, moderate party, earth, age, maturity, dignity, intense, strictness, White House, presidential inauguration, TV, depression, Northern Europe, white, hippie, rock, minimalism, dance, environment, earth, Michelle Obama, religion, reproduction, laborer, pioneer, Great Depression,

Types that the social climate and phenomenon that had an effect on the design inspiration and thinking city, future, London Olympic...

white night, white, nature, land, water, leopard, safari, Capri Island, environment, earth, dirt, sand, hay, essence, object, wind, resort, beach, Sicilian, sea, dawn, honeycombed, farm, grain, scent of flower, flower, wave, texture of wood, wood sculpture, organic material...

Types that the sensibility of nature and formative feature that effect design inspiration and thinking

Gary Hume, film, modernity, Ava Gardner, folklore, military, photograph, cadet, ski, William Thurston, geometry, future city, scuba, originality, stewardess, space, folk costume, remake, sporty, Vincent van Gogh, Antonio Lopez, exhibition, neo design, abstract painting, architecture, Bauhaus, Josef Albers, Steven Meisel...

Types that influence the characteristics of other fields that effect design inspiration and thinking
Mosaic, Cathedral, Belle Du Jour, and Avant-garde.

The results of the network analysis conducted with regard to the design thinking that the contemporary fashion designers pursued by year are summarized with keywords (Table 1).

\section{Types and Examples that the Contemporary Fashion Designers Pursed Regarding the Design Thinking Over the Past Five Years}

Types were categorized into the network analysis conducted for the fashion show concepts from 2009 to 2013: Experiential Aspect that impacted design inspiration and thinking, Social Climate and Phenomenon that impacted design inspiration and thinking, Sensibility of Nature and Formative Feature that impacted design inspiration and thinking and Influence of Other Fields that impacted design inspiration and thinking. A comprehensive summary of types concerning design thinking based on design thinking keywords that contemporary fashion designers pursued are as follows (Table 2).

\subsection{Types that the designer's experiential aspects that} had an effect on the design inspiration and thinking

The types that influenced designer's experiential aspects on the design inspiration and thinking reflect the designer's personal recollections, memory of film (or musical), brand identity that they experienced by extensive work for a specific brand designer, or the atmosphere of the times that they lived in. Designers were shown to either share a public nostalgia of a contemporary period and the sensibilities of experiences or deliver personal thoughts and identity by means of collections.

The representative example of this type is Mulberry at the F/W 2012 London collection where the creative director Emma Hill converted her experience of watching the film 'Where the Wild Things Are' by Spike Jonze into a collection by introducing the characters in the movie. Emma Hill was inspired by the story of the protagonist Max who wore a wool and rabbit fur costume and became the king of a country where monsters resembling an orangutan and chimpanzee lived (Meenal, M. 2012). Fig. 11 shows that the use of rabbit fur and trimmed wool in unified white and gray tones was reminiscent of the wool and rabbit fur costume of the character Max. Fig. 12-13 shows that the use of long for the wild image was emphasized to suggest Max's monster friends like Ira and Carol. The inspiration gained from the movie was expressed through a design that presented costumes to suggest characters in the movie with animalistic materials and voluminous shapes in the collection. Akris F/W 2013 Paris collection by the designer Albert Kriemler is another example who brought memories of his late mother into a collection (Nicole, P. 2013). He reinterpreted the costume items and materials that his mother used to wear into a motive for a contemporary style by transforming a plaid evening dress with see-through fabric with a deeper slit (Fig. 14). He also used suede and calf skin materials that his mother liked to design a patch work mini dress (Fig. 15) and reconfigured them (Fig. 16) to fit contemporary young women by shortening the length above the knee but designed a silhouette that resembled his mother's mink coat to remember his mother.

Experiences influence designers in forming aesthetic perspec- 


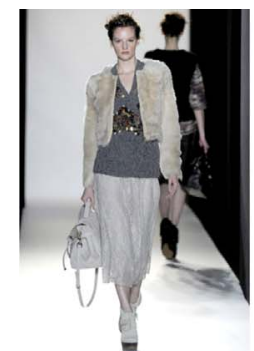

Fig. 11. 2012 F/W

London Mulberry

Collection1.

www.style.co.kr

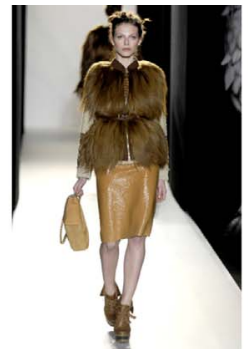

Fig. 12. 2012 F/W

London Mulberry

Collection2.

www.style.co.kr

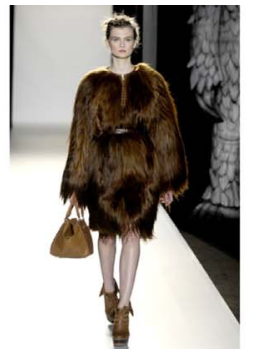

Fig. 13. 2012 F/W London Mulberry

Collection3. www.style.co.kr
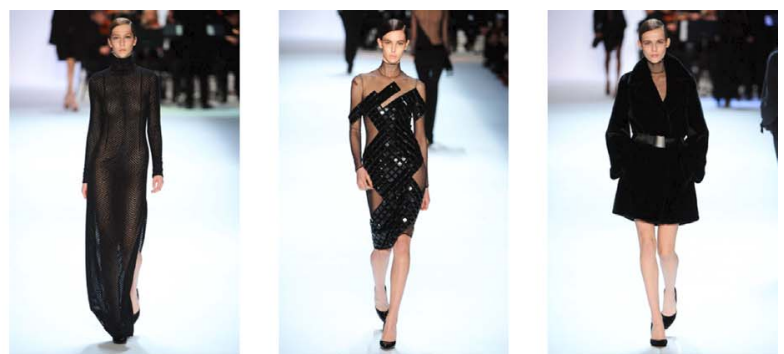

Fig. 14. 2013 F/W Paris Fig. 15. 2013 F/W Paris Fig. 16. 2013 F/W Paris Akris

Collection1. www.style.co.kr
Akris

Collection2. www.style.co.kr
Akris

Collection3. www.style.co.kr tives, design elements, and production methods; consequently, designers express personal memories through design elements like line, silhouette, material, and color that constantly appear in their designs as a specific style. Experience becomes an origin of style as well as the driving force of a designers' creativity.

4.2. Types that the social climate and phenomenon that had an effect on the design inspiration and thinking

The types that the social climate and phenomenon had an effect on the design inspiration and thinking implies the notion that events, movement and political situations that occurred at the time of announcing the collection affect the designers personally or influence the overall atmosphere of collection. Fashion designers who are obliged to be aware of the trends of the times, identified the international situations, economy like finance, politics and ideological conflicts and that were reflected in each designer's collection. Exemplary cases mostly appeared in the S/S and F/W 2009 held during the 2008 Global Financial Crisis and presidential election which influenced design inspiration and thinking.

In the F/W 2009 New York collection, Ralph Lauren expressed helpful and positive messages toward the dark times through cos- tumes that began with the theme of 'let the light in'(Nicole, P. 2009). The collection tried to deliver a message of hope through a desk dress designed with shiny materials (Fig. 17) and also tried to provide a sense of comfort in the depressed economic situations by employing the coat items (Fig. 18). Furthermore, the collection satirized the current era through the patch work costumes (Fig. 19) reminiscent of the film 'Oliver Twist' which is about a boy overcoming the harmful effects and difficulties of industrialization in a harsh society. Michael Kors presented costumes that expressed the social climate of the times and what office workers may wear in real life(Nicole, P. 2009). The costumes suggested a look of a real life girl and anchorwoman in a realistic atmosphere and the seriousness of a rapidly changing era during a financial crisis (Fig. 20) with a slim and slick silhouette black jacket and a narrow skirt as well as a sleeveless black fur (Fig. 21). Economic factors as well as political factors influenced the design inspiration and thinking in the F/W 2009 New York collection by Narciso Rodriguez that presented a khaki twill coat that seemed to reproduce the costume of First Lady Michelle Obama worn at the presidential inauguration in the (Fig. 22). This reflected the social climate and phenomenon that focused on the hope and wishes of America's first black president

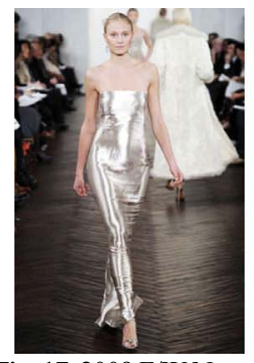

Fig. 17.2009 F/W New York Ralph Lauren Collection1. www.style.co.kr

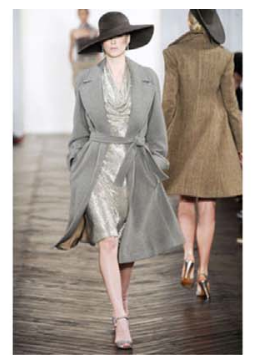

Fig. 18. 2009 F/W New York Ralph Lauren Collection2. www.style.co.kr

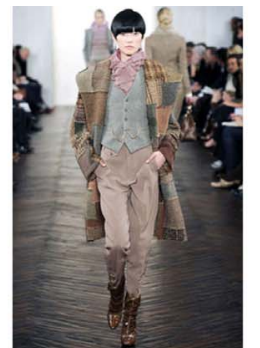

Fig. 19. 2009 F/W New York Ralph Lauren Collection3. www.style.co.kr

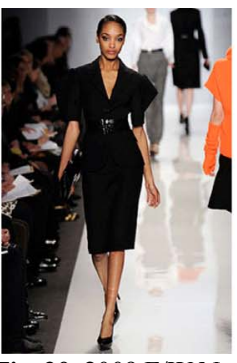

Fig. 20. 2009 F/W Ne York Michael Kors Collection1. www.style.co.kr
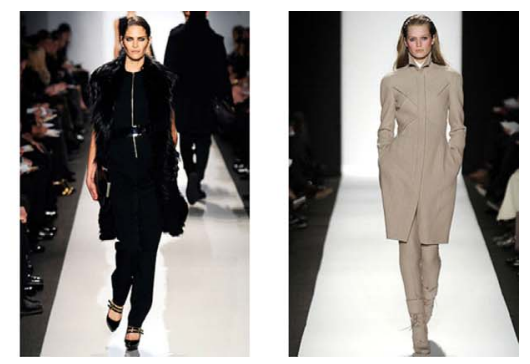

Fig. 22. 2009 F/W New York Michael Kors York Narciso Rodriguez Collection2. www.style.co.kr Collection1. www.style.co.kr 
to overcome the financial crisis .

To articulate such a social climate and phenomenon, the designers expressed hopeful and positive messages that contrasted the dark times through the emission of light using materials. A real life aspect was presented with a practical design through black colors and a slim fit silhouette while indirectly implying the social climate and phenomenon of the times with items that suggested a specific figure.

\subsection{Types that the sensibility of nature and formative} feature that effect design inspiration and thinking

The types that the sensibility of nature and formative feature had an effect on the design inspiration and thinking by applying inspiration not from the artificial elements prevalent in contemporary society but from pure nature like the forest, white night or beach to fashion show stages, design concepts, or ornamental components. Designers tried to deliver natural sensibilities to the audience through designs that frequently appeared in S/S seasons of 2011.

In the F/W 2012 Milan collection, Angelica Missoni said her concept was about 'a story of a girl who wants to lose herself in the wild' and she tried to express the wildness of dirt, rock, moss and trees in Mother Nature (Tim, B, 2012). Fig. 23 shows the gray rock like colors and patterns presented through the sheepskin patchwork top and the stripe skirt (or a tree) embodied through tree bark stripe patterned knee length skirt (Fig. 24). The emerald sea was realized through the jacket and the skirt with geometric patterns and contrasting colors of emerald and gray. Rodarte, in the S/S 2011 New York collection, printed a motif suggesting a serene nature inspired by the scenic view of Northern California (Nicole, P. 2010). Fig. 26 shows the tree ring print reminiscent of the cross section of a cut tree as well as the bark of the tree printed fabrics. The flower printing technique and silk fabric conveyed organic movement of the plants to the audience (Fig. 27). The collection also used flower and foliage ornaments as an organic material onto the costumes result- ing in an Art Nouveau style as in the (Fig. 28).

In this fashion, the designers presented the textures and shapes of organic materials in great detail to express the sensibilities of nature and natural forms through color, texture and the process of materials, and produced the abstract ambience of the sea where the wave rages using geometric patterns and color contrasts. The image of Mother Nature was expressed by printing the tree bark, the cross section of a cut tree and flower patterns directly onto materials.

\subsection{Types that influence the characteristics of other fields that effect design inspiration and thinking}

The types that influence and are the characteristics of other fields that influenced design inspiration and thinking refers to the decisive impact on other areas like arts, science and humanities, including sports, science, architecture, sculpture, painting, and literature. on selecting materials, colors of design and silhouette. They are considered to be the drawing of diverse designs and sharing of broad emotions by compromising and converging with different fields. Representative examples appeared in S/S 2013.

In the S/S 2013 Paris collection, Hermès released a statement that the inspiration came from the architectural beauty of Bauhaus and the abstract paintings of Josef Albers as reflected on the overall silhouette and application of scarves. Silhouettes that expressed a Bauhaus style architecture were boxy or round with a stark color contrast (Tim, B, 2012). The pattern and color organization suggested in Mondrian's paintings were employed in design (Fig. 29) or color combinations that might appear in Kandinsky's abstract paintings as a costume pattern (Fig. 30). The painterly features appeared in the costumes using the yellow, blue and brown colors and arrangements that may have been inspired by a work called 'Homage to the Square' by Josef Albers. In addition, Doo Ri said that she was inspired by 'My Wish under Netting' by the world renowned French installation artist Annette Messager for the S/S

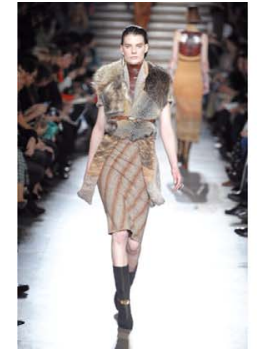

Fig. 23. $2012 \mathrm{~F} / \mathrm{W}$

Milan Missoni Collection1. www.style.co.kr

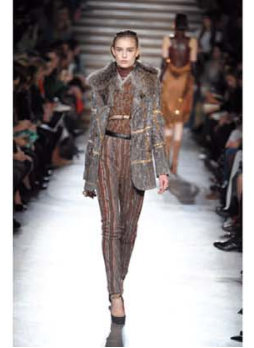

Fig. 24. 2012 F/W

Milan Missoni

Collection2.

www.style.co.kr

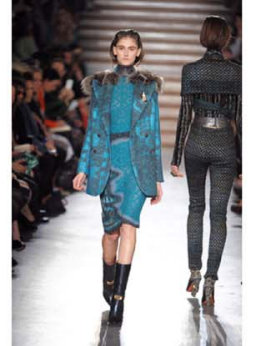

Fig. 25. 2012 F/W

Milan Missoni

Collection3.

www.style.co.kr
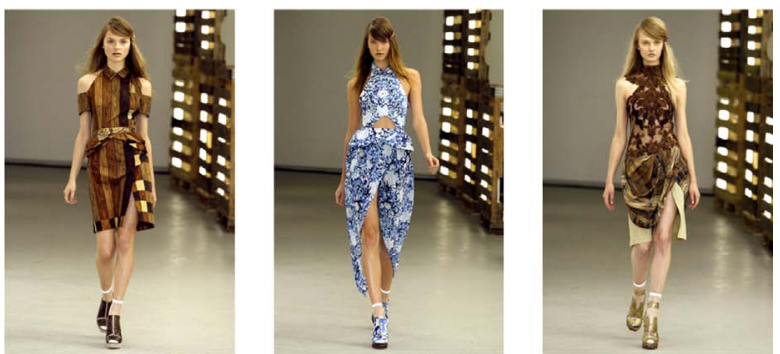

Fig. 26. 2011 S/S New Fig. 27. 2011 S/S New Fig. 28. 2011 S/S New York Rodarte Collection1. www.style.co.kr
York Rodarte

Collection2.

www.style.co.kr
York Rodarte

Collection3. www.style.co.kr 


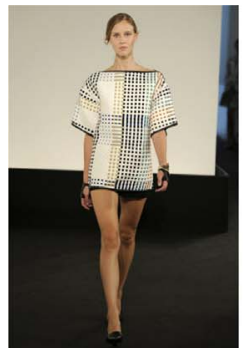

Fig. 29. $2013 \mathrm{~S} / \mathrm{S}$ Paris Hermès Collection1, www.style.co.kr

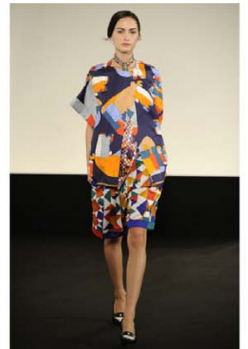

Fig. 30. $2013 \mathrm{~S} / \mathrm{S}$ Paris Hermès Collection2. www.style.co.kr

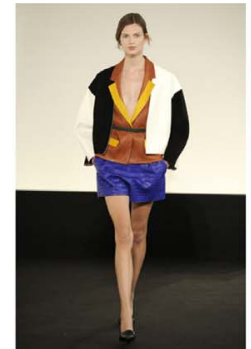

Fig. 31. 2013 S/S Paris Hermès Collection3. www.style.co.kr

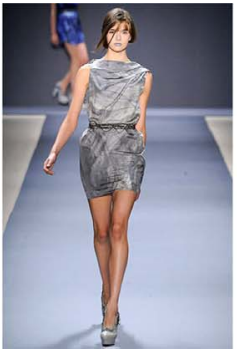

Fig. 32. $2010 \mathrm{~S} / \mathrm{S}$ New York Doo.Ri Collection1, www.style.co.kr

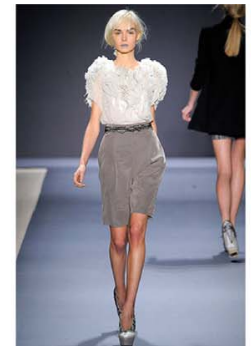

Fig. 33. $2010 \mathrm{~S} / \mathrm{S} \mathrm{New}$ York Doo.Ri

Collection2, www.style.co.kr

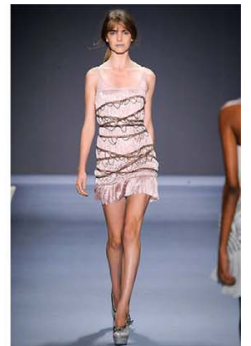

Fig. 34. $2010 \mathrm{~S} / \mathrm{S}$ New York Doo.Ri

Collection3, www.style.co.kr

Table 3. Expressions according to type of design thinking that contemporary fashion designers pursued

Types of design thinking that
$\begin{gathered}\text { contemporary fashion designers } \\ \text { pursued }\end{gathered}$

Types of the designer's experiential - Experience influenced designers in forming aesthetic perspectives, design elements, and production methods aspects that effect design inspiration - Expressed personal recollections and memories through design elements like line, silhouette, material and and thinking colors

Types of the social climate and - Presented hopeful and positive messages in contrast to the dark times by light emitting materials

phenomenon that effected design - Embodied a real life with black color, slim fit silhouette and practical design

inspiration and thinking - Indirectly conveyed the social climate and phenomenon of the times with items that suggested a specific figure

Type of sensibility of nature and - Realized the textures and shapes of natural organic materials in detail through color, texture and process of

materials
formative feature that effect design
inspiration and thinking. inspiration and thinking. $\quad$ - Produced images of Mother Nature by directly printing tree bark, cross sections of a tree and flower patterns

Type of influence and characteristics - Generated an overall silhouette of costumes based on a specific artwork or object

of other fields that effect design - Suggest day masterpiece that uses colors to pay homage

inspiration and thinking - Recreated as an individual design by each designer by distorting and exaggerating existing artwork or objects

2010 New York collection (Nicole, P. 2009). This installation artwork was comprised of metals and square models hanged from the ceiling used to accentuate a costume. Fig. 32-34 shows that the cocktail dresses, sweet little blouses and shorts, tanks, and bubble skirts adorned by thin chains or overlaid with tulle netting. Most of the 30 pieces were in metallic colors of gray and silver that evoked a sense of sharpness.

With the influences of other fields, various designers embodied the shapes of specific artwork, objects as an overall silhouette (or colors) that paid homage as suggested through the works. The designers recreated an individual and personal design through distortion and exaggeration based on existing artworks and objects.

Eexpression methods based on the types of design thinking pursued by contemporary fashion designers (Table 3 ).

\section{Conclusion}

Contemporary fashion develops a constant transformability and customer desire to create a new value concept not limited to art and culture. Fashion designers express personal thoughts along with various areas of society, art, literature, nature, and economics.

This research is a comprehensive analysis of fashion trends from S/S 2009 to F/W 2013 through fashion show concepts by contemporary fashion designers and through a network structure analysis. The conclusions of this research are as follows. First, the results of the network analysis regarding design thinking around the fashion show that the contemporary fashion designs pursued over the past five years demonstrate that S/S and F/W 2009 focused on experiential aspects of designers, social climate and phenomenon, S/S 2010 was about experiential aspects with the inspiration and formative properties of nature and F/W 2010 was about experiential aspects. The inspirations and formative properties of nature were dominant in S/S 2011; however, the influences and qualities of the other fields were prevalent in F/W 2011 and S/S 2012. F/W 2012 was more into experiential aspects and S/S 2013 was interested in the influences and qualities of other fields; how- 
ever, F/W 2013 was into the experiential aspects and the influences and qualities of other fields. The types that influenced design inspiration and thinking can be summarized into four categories: experiential aspects of a designer, the social climate and phenomenon, the inspirations and formative properties of nature and the influences and qualities of other fields. Second, the case where the designer's experiences impact their design inspiration and thinking can be expressed with keywords such as High School, Grandmother's Closet, Prom, The Beauty And The Beast, Inheritance, Past and Retrospect. The designers conveyed their private recollections, memories of watching films and musicals, the brand identity that they experienced by extensive work for a specific brand and ambience experienced in the past. Third, the representative examples of the social climate and phenomenon that effected design inspiration and thinking are the S/S and F/W 2009 collections with keywords such as Recession, Black, Economy, US, Depression, Gray, Dark Age, White and New York that reflected the social atmosphere of the 2008 Global Financial Crisis. Fourth, when the inspiration and natural properties of nature influenced design inspiration and thinking, the designers applied ideas gained from nature to collection concepts and ornamental elements related by words from nature such as light, sun, wild, dirt, rock, moss, and trees. Fifth, for the case of other fields and their properties that influenced the design inspiration and thinking, designers took elements from the arts, science, or humanities (sports, architecture, sculpture, painting, and literature) as a decisive factor to select materials, design colors and silhouettes. Architecture (which appears every year) was analyzed as a key element impacting the designers' concepts.

In conclusion, this research explored the relationships between social and environmental elements and designers' concepts through a network analysis that targeted contemporary fashion design concepts. This research identified creative thinking and designer trends and established an archive for the next generation. The results can be used broadly as educational material on the subject of academic value improvement and future design thinking. A wide range of research methodologies and analysis techniques incorporated in the clothing area of this research will be incorporated into the post research analysis of apparel with further integrated thinking.

\section{Acknowledgement}

This work was supported by the National Research Foundation of Korea Grant funded by the Korean Government (NRF2014S1A5A2A01016109).

\section{References}

'2009 F/W New York Michael Kors Collection1'. (n. d.). style.com. Retrieved October 1, 2014, from http://www.style.co.kr/collection/ view.asp?scd_code $=1669 \# 104568 \_3 \_5$

'2009 F/W New York Michael Kors Collection2'. (n. d.). style.com Retrieved October 1, 2014, from http://www.style.co.kr/collection/ view.asp?scd_code=1669\#104537_1_2

'2009 F/W New York Narciso Rodriguez Collectionl'. (n. d.) style.com. Retrieved October 1, 2014, from http://www.style.co.kr/ collection/view.asp?scd_code $=1670$

'2009 F/W New York Ralph Lauren Collection1'. (n. d.). style.com. Retrieved October 1, 2014, from http://www.style.co.kr/collection/ view.asp?scd_code=1672\#105087_4_2

'2009 F/W New York Ralph Lauren Collection2'. (n. d.). style.com. Retrieved October 1, 2014, from http://www.style.co.kr/collection/ view.asp?scd_code $=1672 \# 105070 \_2$ _13

'2009 F/W New York Ralph Lauren Collection3'. (n. d.). style.com. Retrieved October 1, 2014, from http://www.style.co.kr/collection/ view.asp?scd_code $=1672 \# 105061 \_2 \_4$

'2010 S/S New York Doo.Ri Collection1'. (n. d.). style.com. Retrieved October 1, 2014, from http://www.style.co.kr/collection/ view.asp?scd_code=1975\#126987_1_10

'2010 S/S New York Doo.Ri Collection2'. (n. d.). style.com. Retrieved October 1, 2014, from http://www.style.co.kr/collection/ view.asp?scd_code=1975\#126991_2_0

'2010 S/S New York Doo.Ri Collection3'. (n. d.). style.com. Retrieved October 1, 2014, from http://www.style.co.kr/collection/ view.asp?scd_code $=1975 \# 127003 \_2 \_12$

'2011 S/S New York Rodarte Collection1'. (n. d.). style.com. Retrieved October 1, 2014, from http://www.style.co.kr/collection/ view.asp?scd_code=2152\#149091_1_8

'2011 S/S New York Rodarte Collection2'. (n. d.). style.com. Retrieved October 1, 2014, from http://www.style.co.kr/collection/ view.asp?scd_code $=2152 \# 149102 \_2 \_5$

'2011 S/S New York Rodarte Collection3'. (n. d.). style.com. Retrieved October 1, 2014, from http://www.style.co.kr/collection/ view.asp?scd_code $=2152 \# 149086 \_1$ _3

'2012 F/W London Mulberry Collection1'. (n. d.). style.com. Retrieved October 1, 2014, from http://www.style.co.kr/collection/ view.asp?scd_code=2594\#182990_1_10

'2012 F/W London Mulberry Collection2'. (n. d.). style.com. Retrieved October 1, 2014, from http://www.style.co.kr/collection/ view.asp?scd_code $=2594$

'2012 F/W London Mulberry Collection3'. (n. d.). style.com. Retrieved October 1, 2014, from http://www.style.co.kr/collection/ view.asp?scd_code=2594\#182980_1_0

'2012 F/W Milan Missoni Collection1'. (n. d.). style.com. Retrieved October 1, 2014, from http://www.style.co.kr/collection/ view.asp?scd_code $=2665 \# 186533 \_1 \_2$

'2012 F/W Milan Missoni Collection2'. (n. d.). style.com. Retrieved October 1, 2014, from http://www.style.co.kr/collection/ view.asp?scd_code $=2665 \# 186545 \_2$ _0

'2012 F/W Milan Missoni Collection3'. (n. d.). style.com. Retrieved October 1, 2014, from http://www.style.co.kr/collection/ 
view.asp?scd_code $=2665 \# 186561 \_3 \_2$

'2013 F/W Paris Akris Collection1'. (n. d.). style.com. Retrieved October 1, 2014, from http://www.style.co.kr/collection/ view.asp?scd_code $=2946 \# 202389 \_213$

'2013 F/W Paris Akris Collection2'. (n. d.). style.com. Retrieved October 1, 2014, from http://www.style.co.kr/collection/ view.asp?scd_code $=2946 \# 20239434$

'2013 F/W Paris Akris Collection3'. (n. d.). style.com. Retrieved October 1, 2014, from http://www.style.co.kr/collection/ view.asp?scd code $=2946 \# 20237822$

'2013 S/S Paris Hermès Collection1'. (n. d.). style.com. Retrieved October 1, 2014, From http://www.style.co.kr/collection/ view.asp?scd_code $=2768 \# 191333 \_1 \_1$

'2013 S/S Paris Hermès Collection2'. (n. d.). style.com. Retrieved October 1, 2014, from http://www.style.co.kr/collection/ view.asp?scd_code $=2768 \# 191358 \_2 \_12$

'2013 S/S Paris Hermès Collection3'. (n. d.). style.com. Retrieved October 1, 2014, from http://www.style.co.kr/collection/ view.asp?scd_code=2768\#191361_3_1

'Collection'. (n. d.). The National Institute of the Korean Language. Retrieved June 1, 2015, From http://www.korean.go.kr

'Concept'. (n. d.). The National Institute of the Korean Language. Retrieved December 12, 2014, From http://www.korean.go.kr

'Design'. (n. d.). The National Institute of the Korean Language. Retrieved December 12, 2014, From http://www.korean.go.kr

'Theme' (n. d.). Doosan Encyclopedia Doopedia. Retrieved June 1, 2015, From http://www.doopedia.co.kr/doopedia/master/ master.do?_method=view\&MAS_IDX $=101013000735420$

Burns, L. D., \& Bryant, N. O. (2002). The Business of Fashion (2nd ed.). New York: Fairchild Publications, Inc.

Choi, I. Y. (2009). The Basic Elements for Developing Creative Design Concept. Journal of the Korean Society of Costume, 10(2), 499-509.

Choi, Y. M. (2001). Generating creative idea and developing model in fashion design. Unpublished doctoral dissertation, Seoul National University, Seoul.

Chung, D. H., \& Yoo, D. Y. (2013). A Communication Structure of Science Gifted Students Based on the Social Network Analysis. Journal of the Korean Earth Science Society, 34(1), 81-92.

Essence Korean language dictionary. (2013). Paju: Minjungseorim.

Hong, J. H., \& Jang, J. H., \& Cho, Y. H. (2014). Diachronic Network Analysis of South Korea's Presidential Speeches on the Economy: from 1948 to 2008. Korean Society and Public Administration, 25(1), 53-93.

Kim, A. N. (2003). Family and Social Networks : A Comparative Analysis of Personal Relationships in Germany and South Korea. Korean Journal of Sociology, 37(4), 67-99.

Kim, H. Y. (2003). Psychological Assessment of Regional and Emotional Images Reflected in Design Theme -Centering round on the futurism appeared in Paris, Milan, London, New York Fashion Collections-. Journal of Korean Society, 27(3/4), 343-353.

Kim, M. C. (2012). Analysis of trench coat design by the fashion design idea method. Unpublished master's thesis, Gyeongsang National University, Busan.

Kim, U. S. (2012). Contribution of Classical Social Theories on the Construction and Transformation of Social Networks: From Marx, Weber, and Durkheim. Discourse 201, 15(3), 5-27.
Kim, Y. K. (2014). Study on Characteristics of the Development Process of Fashion Design Thinking through the Lexicon. Journal of the Korean Society of Costume, 64(2), 113-125.

Kim, Y. S. (2010). A study on fundamental phenomena of fashion effected by perception and memory. Unpublished doctoral dissertation, Hongik University, Seoul.

Ko, K. K. (2007). The Review of Studies on Policy Network and the Application of Social Network Analysis. Korean Journal of Public Administration), 45(1), 137-164.

Kong, M. S. (2003). A study on the expansion methodology of creative fashion design. Unpublished doctoral dissertation, Sookmyung Women's University, Seoul.

Lee, K. H. (2007). A study on the constructive design techniques of apparel : Focusing with constructive of line and plane. Unpublished master's thesis, Hongik University, Seoul.

Lee, M. S. (2013). A comparative study on influencing factors of creativity of fashion designers : centered on perspectives of $M$. Csikszentimihalyi \& H. Gardener. Unpublished doctoral dissertation, Seoul National University, Seoul.

Lee, Y. K. (2006). A research on the conception of fashion design analyzed by check list method. Unpublished master's thesis, Kookmin University, Seoul.

Meenal, M. (2012, February 19). Fall 2012 Ready-to-Wear Mulberry. Style.com. Retrieved October 1, 2014, from http://www.style.com/ fashion-shows/fall-2012-ready-to-wear/mulberry

Nam, Y. J. (2012). A study on transformable fashion design by the idea of conversion. Unpublished doctoral dissertation, Ewha Womans University, Seoul.

Nicole, P. (2009, February 18). Fall 2009 Ready-to-Wear Michael Kors Collection. Style.com. Retrieved October 1, 2014, from http:// www.style.com/fashion-shows/fall-2009-ready-to-wear/michaelkors

Nicole, P. (2009, February 20). Fall 2009 Ready-to-Wear Ralph Lauren. Style.com. Retrieved October 1, 2014, from http:// www.style.com/fashion-shows/fall-2009-ready-to-wear/ralphlauren

Nicole, P. (2009, September 16). Spring 2010 Ready-to-Wear Doo.Ri. Style.com. Retrieved October 1, 2014, from http://www.style.com/ fashion-shows/spring-2010-ready-to-wear/doo-ri

Nicole, P. (2010, September 14). Spring 2011 Ready-to-Wear Rodarte. Style.com. Retrieved October 1, 2014, from http://www.style.com/ fashion-shows/spring-2011-ready-to-wear/rodarte

Nicole, P. (2013, March 3). Fall 2013 Ready-to-Wear Akris. Style.com. Retrieved October 1, 2014, from http://www.style.com/fashionshows/fall-2013-ready-to-wear/akris

Park, E. S., \& Choi, M. S. (2011). The Effect of Learners` Social Network Centralities on Knowledge Construction in Online Debating Learning. The Journal of Educational Information and Media, 17(3), 353-377.

Park, S. H. (2009). Semantic Network Analysis of Presidential Debates in 2007 Election in Korea. Korean Journal of Communication \& Information, 45, 220-254.

Perna, R. (1987). Fashion Forecasting. New York: Fairchild Publications, Inc.

Shin, H. C. (2008). Network Analysis of Globalization-related Contents in Highschool Social Studies Textbooks. Unpublished master's thesis, Pukyong National University, Pusan. 
Tim B. (2012, February 26). Fall 2012 Ready-to-Wear Missoni. Style.com. Retrieved October 1, 2014, from http://www.style.com/ fashion-shows/fall-2012-ready-to-wear/missoni

Tim B. (2012, September 30). Spring 2013 Ready-to-Wear Hermès. Style.com. Retrieved October 1, 2014, from http://www.style.com/ fashion-shows/spring-2013-ready-to-wear/hermes

(Received 15 April 2015; 1st Revised 1 June 2015; 2nd Revised 22 June 2015; Accepted 30 June 2015)

(C) 2015 (by) the authors. This article is an open access article distributed under the terms and conditions of the Creative Commons Attribution license (http://creativecommons.org/licenses/by/3.0/), which permits unrestricted use, distribution, and reproduction in any medium, provided the original work is properly cited. 